\title{
ART SPACE: AN EXPERIMENTAL DIGITAL ART GAM
}

\author{
Ieva Gintere \\ Vidzeme University of Applied Sciences, Latvia
}

\begin{abstract}
The article examines the discourse concerning modern game theory and suggests a new method of research and knowledge transfer in the field of digital art game creation. The method is embodied in the new game Art Space that utilizes current research results in the field of contemporary aesthetics. Art Space is an experimental digital game that is being created in collaboration between researcher, Dr.art. Ieva Gintere (Vidzeme University of Applied Sciences, Latvia) and the game artist, Mag.art. Kristaps Biters (Liepāja University, Latvia) within the framework of a post-doctoral project. The concept of this new art game arises from the historical heritage of modern art. The aim of the game is knowledge transfer: the author has been carrying out research into contemporary digital games in order to transfer the results of the research to develop an appreciation and understanding of aesthetics in Art Game's players. The game links aesthetics to art games by identifying modern trends such as pixel art, glitch, noise, and others. Due to the dearth of written information on the subject of modern art heritage in digital games, the study presents an innovative approach to art gaming explaining modern art's cultural backgrounds. The methods used are audio-visual and stylistic analyses of games as well as studies of the existing literature. The project hopes to raise the interest of the wider public concerning contemporary art and music, point out the newest creative tendencies in art, and suggest potential changes in the language of art in the near future. This paper continues previously published research that helped to create the concept and design of Art Space, and focuses on the trends of photorealism and futurism.
\end{abstract}

Keywords: aesthetics of modernism, digital art game, futurism, knowledge transfer, photorealism.

\section{Introduction}

This research project aims to create a new profile of art games that would exemplify modern interdisciplinary and analytic thought. The paper deals with the problem of cultural segregation and the knowledge cache that characterizes modernism. The art of the modernism tradition is highly specific and difficult for a large segment of the public to access. Its store of knowledge is mainly directed to members of the public with a specific intellectual background. Modern art is a coded area that mostly demands a specific education in order to be understood. The aim of this study is to bring modern arts' capital of knowledge outside its traditionally narrow social space and to transfer this knowledge to the general 
public. Contemporary art theory with its highly intellectual capital of knowledge can be effectively activated and shared in the area of art games.

This paper is built on a basis of literature analysis (discourse about game theory) and art game analysis. Around 200 art games have been analyzed in the course of this research. The art game discourse is a quite narrow field that rests upon general gaming theory, however art gaming is a specific field and its analysis requires a particular theoretical approach. This article seeks to develop the existing digital art game methodology. The author suggests creating art games on the basis of research and the games historical backgrounds in order to transfer knowledge to the game players. There are a lot of art games that express the ideas of artists and the spirit of our century i.e., games created by Pippin Barr, Jason Rohrer, and many other digital artists. While the field of art gaming lacks the aspect of knowledge transfer, it does embody aesthetical features, and could be used as an effective media to inform and educate players. It could show the full picture of modern art, and the results of the contemporary art research. The author's assertion is that art gaming should inform the player about how the art of today is related to art history, and what links contemporary art has to the previous art paradigms. There should be a category of art games that explain modern art trends in the context of their past. Art gaming could be an effective tool for disseminating the results of research in the field of contemporary art.

\section{Discourse of the Game Theory: The Aspect of Knowledge Transfer}

In search of an advanced game methodology, the game theorist Igor Mayer and his colleagues suggest a methodological approach that would include "a critical and reflective discourse on a dynamic body of knowledge identifying the state of the art and knowledge gaps". This is needed, he advocates, because of a responsibility to "critically reflect on the short- and long-term value" of the serious games (Mayer et al., 2014, p. 504). Many authors agree that research is a meaningful part of game creation; however, the aspect of sharing the research results with the player in a comprehensible way that could be called knowledge transfer has been almost left aside so far. For instance, Katrin Becker and Jim Parker present a methodological model that involves research, but has no knowledge transfer (Becker \& Parker, 2014, pp. 181, 189). Marcos S.O. Almeida and Flávio S.C. da Silva present a visual model of game design (Almeida, da Silva, 2013, p. 20), but the model does not include knowledge transfer. As Annika Waern and Jon Back have put it, "there exist very little meta-level discussion of the kinds of knowledge that is the result of design research on games". (Waern \& Back, 2015, p. 350).

The existing theoretical principles offered by the game researchers are not shaped for art games in particular and there is no focus on knowledge transfer. 
For instance, there is a multi-dimensional model of games that underlines the aspects of representation, teleology (Elverdam \& Aarseth, 2007), and functions of the game: avoid, shoot, match (Djaouti, Alvarez, Jessel, \& Methel, 2008). Other groups of researchers concentrate on the gameplay, purpose, thematic field, or audience (Djaouti, Alvarez, \& Jessel, 2011). None of those models take into account the dimension of knowledge transfer. Mary Flanagan's humanist approach and her idea of "critical play" (Flanagan, 2009, p. 256) is closer to the idea of an intellectual capital that should be transferred to the player. Flanagan states that games have to emerge out of intellectual traditions. The game should be rooted, she says, in the intellectual traditions and its authors should always seek for a socially important message.

\section{Contribution to the Art Game Studies: The Aspect of Historical Background}

As well as the aspect of knowledge transfer, this project intends to fill the gap of aesthetical analysis in the game discourse where only a few examples contain references to the historical styles and aesthetical theory of the games. Celia Pearce, Alican Koc and some others are among the authors who have paid attention to this subject. Pearce touches upon the heritage from fluxus and dada and shows its importance in the conception of hacking in games (Pearce, 2006), Koc uniquely clarifies the important reference to Immanuel Kant's aesthetics in the context of the trend of vaporwave (Koc, 2017). Christiane Paul shows the manifold tendencies of modern gaming such as hypertextuality, random access and others using their historical background (Paul, 2003). Abstractionism is a well-recognized category of games, and its relation to abstract art has been explained, for instance, by calling the abstract style in video games "an extension of abstract art" (Wolf, 2003, p. 47). Other authors seem to forget that and use the term "abstractionism" with a universal meaning without mentioning its historical origin in the context of visual art (Gee \& Dolah, 2018). Photorealism as a successor of this artistic style is present in the discourse of games, too (Jakdonlan, 2019), even if an exact reference to the era of modernism is sometimes missing (Järvinen, 2002, p. 121). Stephen Kleckner mentions the historical futurism in games underlining the political aspect that might give some negative connotations to the term (Kleckner, 2014).

In her captivating book, Johanna Drucker touches upon the Bauhaus heritage in digital art (Drucker, 2014, p. 35) that would also be topical in art games, but there is no focus on the artistic aspects of gaming in this work. In the discourse of digital aesthetics, there is a comprehensive analysis of web page design that contains traces of modernism trends such as glitch and deconstruction (Pring, 2003, p. 142; Wiedemann, 2002, p. 575). During the last decades of $20^{\text {th }}$ century, 
web pages are evidently influenced by the stylistics of modernism. Games are not the subject of these books, yet since website design is an area related to the games, these sources can be used to study the features that are common to games and web design. Matīss Kūlis, the Latvian theorist, has published a magnificent book about interface aesthetics that shows the influences of modernism in graphic design. This work is only available in Latvian, but it is a valuable input into the discourse of modernism heritage that covers the tendencies of futurism, cubism, constructivism, surrealism, minimalism and others that form the background of contemporary gaming (Kūlis, 2015). There is a considerable number of monographs about digital art's tendencies (Kane, 2014; Lieser, 2010; Lovejoy, 2004; Grant \& Vysniauskas, 2004; Grau, 2003, and others), nevertheless, there are no contributions to the modernism heritage in art games in particular and no comprehensive stylistic analysis. Yet art games show a great variety of stylistics inherited from modernism that recall the meaningful cultural backgrounds, shed light on modern thought in art and can help to write contemporary art's history.

\section{Concept of the New Art Game}

This paper utilizes the research results of the European Regional Development Fund project (see Acknowledgements), named Leveraging ICT Product Innovations by Enhancing the Codes of Modern Art. The task of this project is to create an innovative digital game in the cross-cutting genres of art games and serious games with a mission to support knowledge transfer of modern art to the contemporary game players. The new game Art Space presents the specific aspects of digital art games and their historical background rooted in the era of modernism. The goal of the game is to integrate the general public into contemporary aesthetics and to seek new means of artistic expression in the current interactive digital culture.

Art Space should develop the creative skills of players and teach them the current trends in digital art. It should inform the players about the aesthetics of contemporary art, coaching them to understand the off springs of modernism and speculate about the future forms of art. It should illuminate the heritage from the age of modernism into the digital world by teaching the player to recognize it (for instance, the deconstructed forms in the art games are successors to the futurism movement in modernism).

Art Space is a sandbox style game where the player can create, manipulate, and edit visual and audio objects in the environment. Its mechanics allow the user to act creatively with the provided tools. The player will see the world from a firstperson perspective using the standard first person shooter controls with additional editing options. 
Proceedings of the International Scientific Conference. Volume V, May $22^{\text {th }}-23^{\text {th }}, 2020.649-660$

Table 1 Artistic Trends in Art Space with Contemporary and Historical Examples

\begin{tabular}{|c|c|c|c|}
\hline $\begin{array}{c}\text { Type of } \\
\text { aesthetics }\end{array}$ & Characteristics & $\begin{array}{c}\text { Examples of } \\
\text { contemporary games } \\
\text { and game art works } \\
\end{array}$ & Antecedents \\
\hline Photorealism & $\begin{array}{l}\text { Expressive quality, photo- } \\
\text { realistic modeling, familiar } \\
\text { objects, high level of detail, } \\
\text { realistic shadow casting }\end{array}$ & $\begin{array}{c}\text { Evil Interiors (2003), The } \\
\text { Outlands (2011), } \\
\text { Dear Esther (2012) }\end{array}$ & $\begin{array}{l}\text { Bechtle. '61 Pontiac } \\
\text { (1968-69) }\end{array}$ \\
\hline Futurism & $\begin{array}{l}\text { Symbols of speed, violence, } \\
\text { and dynamics; disjointed } \\
\text { figures, multiplied forms; } \\
\text { fantasy world of cyber- } \\
\text { consciousness }\end{array}$ & $\begin{array}{l}\text { Recurse (2010), Fotonica } \\
\text { (2011), } \\
\text { Race the Sun (2013), } \\
\text { Smash Hit (2014) }\end{array}$ & $\begin{array}{l}\text { Duchamp. Nude } \\
\text { Descending A } \\
\text { Staircase (1912), } \\
\text { Balla. Espansione } \\
\text { dinamica (1913) }\end{array}$ \\
\hline Glitch & $\begin{array}{l}\text { Various forms of audio- } \\
\text { visual disturbances for } \\
\text { artistic purposes }\end{array}$ & $\begin{array}{l}\text { Untitled Game (1996), } \\
\text { Memory Of A Broken } \\
\text { Dimension (2015) }\end{array}$ & $\begin{array}{c}\text { Van Gogh. Bedroom } \\
\text { In Arles (1888), } \\
\text { Cézanne. Nature } \\
\text { morte aux oignons } \\
\text { (1898) }\end{array}$ \\
\hline Pixel art & $\begin{array}{l}\text { Small pixel-like shapes, } \\
\text { robust forms, } \\
\text { low in the level of detail, } \\
\text { flat shadings }\end{array}$ & $\begin{array}{c}\text { Passage (2007), } \\
\text { Every Day The Same } \\
\text { Dream (2009), } \\
\text { Nidhogg (2014), } \\
\text { The Pyramid Gate (2014) }\end{array}$ & $\begin{array}{c}\text { Picasso. Les } \\
\text { Demoiselles } \\
\text { d'Avignon (1907), } \\
\text { Stepanova. Costumes } \\
\text { (around 1920) }\end{array}$ \\
\hline Hacking & $\begin{array}{l}\text { Breaking the identity of the } \\
\text { original piece / work of art }\end{array}$ & $\begin{array}{l}\text { The Intruder (1999), } \\
\text { Nude Raider I \& II } \\
\text { Patches (1999), } \\
\text { [domestic] (2003) }\end{array}$ & $\begin{array}{c}\text { Duchamp. L.H.O.O.Q. } \\
\text { (1919), } \\
\text { Rauschenberg. } \\
\text { Erased de Kooning } \\
\text { Drawing (1953) }\end{array}$ \\
\hline $\begin{array}{l}\text { Generative } \\
\text { art }\end{array}$ & $\begin{array}{c}\text { Principle of self- } \\
\text { organization: } \\
\text { objects partly created } \\
\text { autonomously; } \\
\text { biological principle of self- } \\
\text { organized growth; } \\
\text { randomness } \\
\end{array}$ & $\begin{array}{l}\text { Eufloria (2009), } \\
\text { Diablo (2013), } \\
\text { Bellwoods (2018) }\end{array}$ & $\begin{array}{l}\text { Duchamp. The Large } \\
\text { Glass (1915-1923), } \\
\text { Cage. Music of } \\
\text { Changes (1951) and } \\
\text { 4'33”'(1952) }\end{array}$ \\
\hline Noise music & $\begin{array}{l}\text { "Unmusical” sounds: } \\
\text { cracking, hiss, hum, and } \\
\text { other sounds of digital } \\
\text { distortion }\end{array}$ & $\begin{array}{l}\text { Untitled Game (1996), } \\
\text { SOD (1999), } \\
\text { Memory Of A Broken } \\
\text { Dimension (2015) }\end{array}$ & $\begin{array}{c}\text { Stockhausen. } \\
\text { Studie I (1953), Ligeti. } \\
\text { Poème symphonique } \\
\text { for } 100 \text { metronomes } \\
\text { (1962) }\end{array}$ \\
\hline Kitsch/camp & $\begin{array}{c}\text { Vulgar, bizarre, and showy } \\
\text { aesthetics; excessive } \\
\text { garishness; irony, } \\
\text { humorous expression }\end{array}$ & $\begin{array}{c}\text { Painting (2018), } \\
\text { Pin Pon (2015), } \\
\text { Bananoculus (2015) }\end{array}$ & $\begin{array}{c}\text { Matisse. } \\
\text { Red Room (1908), } \\
\text { Dix. Salon } 1 \text { (1927) }\end{array}$ \\
\hline Naïve art & $\begin{array}{c}\text { Childlike simplicity, } \\
\text { frankness, hand drawn } \\
\text { characters, usually bright } \\
\text { colors, lack of perspective }\end{array}$ & $\begin{array}{c}\text { Blueberry Garden (2009), } \\
\text { Monument Valley (2014), } \\
\text { Samorost (2003, 2005, } \\
\text { 2016) }\end{array}$ & $\begin{array}{c}\text { Klee. Red Bridge } \\
\text { (1928), } \\
\text { Miró. The Sun (1949) }\end{array}$ \\
\hline
\end{tabular}


In order to create feedback, the game integrates its players into the research. The game functions as a platform for new knowledge acquisition, while the secondary task of the game is to collect the players' results in order to analyze any new creative tendencies and to predict the art trends of tomorrow.

Art Space is structured in the following sectors delineating the contemporary trends in the art game aesthetics (Table 1).

\section{Photorealism}

This paper continues previously published research that helped to create the concept and design of Art Space (Gintere, 2020; Gintere, 2019a; Gintere, 2019b; Gintere, 2018), and focuses on the trends of photorealism and futurism. Photorealism is one of the newest tendencies in the digital art game field inherited from the era of postmodernism. Photorealism appeared in American painting in the late 1960's and 1970's represented by artists Robert Bechtle (b. 1932), John Baeder (b. 1938), Tom Blackwell (b. 1938), and others who intended to depict objects as realistically as possible so that the result would remind viewers of photography. In the area of art games, the use of photorealism is considered unusual because digital media is traditionally associated with geometrical figures. Photorealism is said to be "alien to the deep-seated nature" of the digital medium which works with mathematical equations, and "visualizes the images obtained by means of pixels" (Quaranta, 2006, p. 305). There is a large number of games that fall under the category of pixel aesthetics, both in the field of art games and in the mainstream gaming. Also, geometrical forms are a widespread means of expression in the art game field. Antichamber (2013), Please Say Something (2011), and Flywrench (2007) could be mentioned among the most interesting ones.

Nevertheless, photorealism has become a noticeable tendency in art games with its smooth images and ability to "render the gap between fantasy and reality harder to perceive" (Quaranta, 2006, p. 304). Photorealism is represented in the art game Dear Esther (Fig. 1) showing wonderful, realistic scenes of nature (The Chinese Room, 2012). It is used also in the new media art related to the game field. Palle Torsson in his Evil Interiors (2003) used the editor of Unreal Tournament to depict the interiors of some of the key scenes in famous horror films such as Psycho, The Silence of the Lambs, and others (Quaranta, 2006, p. 304). John Paul Bichard used the videogame Max Payne 2 to create The White Room (2004). It is a set of manipulated gamespace interiors resulting from an ingame photo shoot (Jansson, 2010). The Outlands by David Haines and Joyce Hinterding is a virtual reality environment built with the Unreal Game engine. It invites visitors to conduct their voyage through an immersive digital world of forests, islands and futuristic interiors (Haines, Hinterding, 2011). 


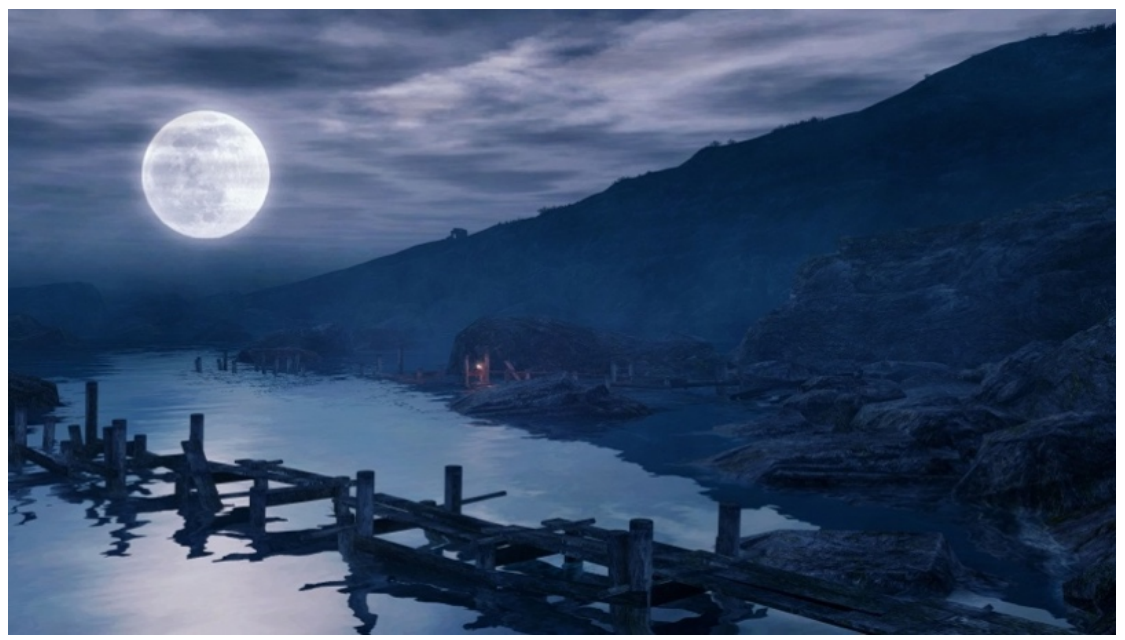

Figure 1 Dear Esther, screenshot (Diver, 2017)

\section{Futurism}

Next to photorealism, futurism is another tendency that marks the roots of modernism in the area of art games. Futurism is an art trend from the early $20^{\text {th }}$ century that uses symbols of speed, violence and dynamics. Marcel Duchamp (1887-1968), Gino Severini (1883-1966), and other futurists glorified the fast movement which resulted in disjointed figures. The forms in futurism painting are often multiplied to show a rapid movement. Futurism is closely related to cubism, both of them use deconstructed geometrical figures. In futurism, there is more disintegration and diffusion thanks to the effect of dynamics (Fig. 2).

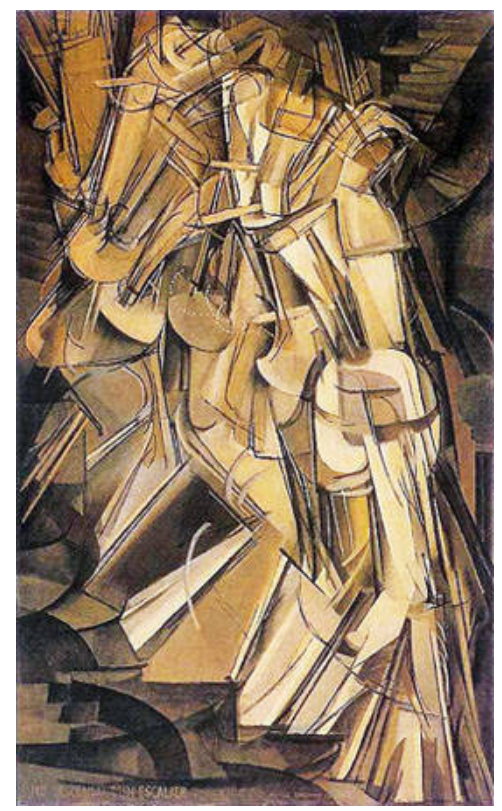

Figure 2 Marcel Duchamp. Nude Descending a Staircase (1912) (Homolka, Price, Sutherland, 2007: 46) 
In the domain of art gaming, not to mention mainstream gaming, disconnected figures flying in space in a dynamic action are a significant gesture. Decomposition, dissolved forms, and disrupted elements are some of the basic means of expression to represent energy and power in gaming. The art games representing the futurism heritage that should not be overlooked, are Recurse, Bound and Fotonica. Recurse (2010) is a significant work that shows dissolved, distorted forms that occur as the player moves his/her body in a physical space. The dynamics of geometrical objects can also be seen in Fotonica (2011). Superhot (2016) is another game that could be mentioned among the futurism successors even if it is not classified as an art game. Superhot shows the typical action related to the futurism, as well as the cubistically broken forms flying in the space. Bound exemplifies moving geometrical objects as the player navigates a narrow beam or an unstable platform (Plastic Studios, 2016) (Fig. 3).

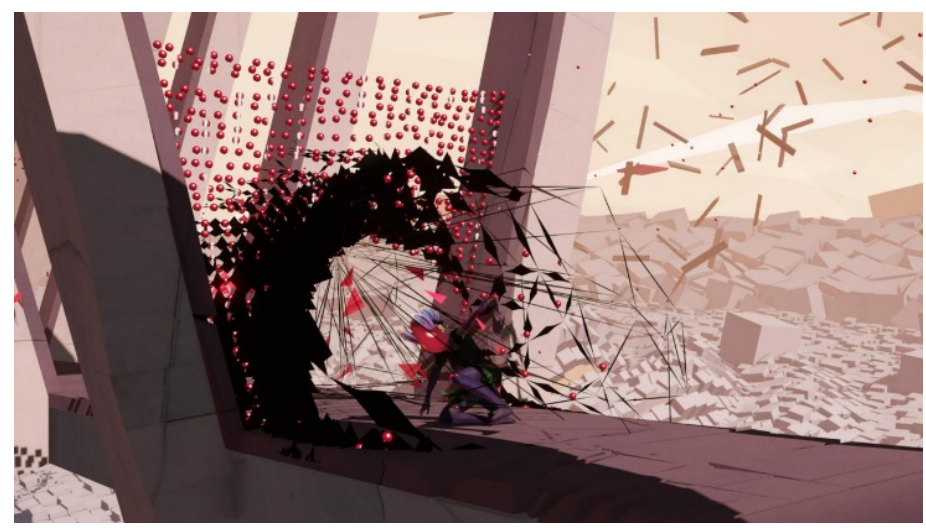

Figure 3 Bound, screenshot (Clark, 2016)

The technologies of tomorrow will also likely reflect the presence of futurism in the area of gaming. It is common to use the images of futuristic technologies in videogames just as it was in the futurism style. Games like Race the Sun (2013), MirrorMoon EP (2013), Smash Hit (2014) and Fract (2014) are typical of this genre. They manifest cubism-like flying, dissociate forms, dynamic power and the "fantasy world of cyber-consciousness" with its technological advances (Kleckner, 2014).

The theoretical framework of the game demands a detailed description that exceeds the limits of the current paper, therefore, only two trends, futurism and photorealism, have been examined in this article. All the mentioned stylistic tendencies function as a means of expression in Art Space. Futurism is an aesthetical approach used commonly in mainstream gaming and art games. It was inherited from the early modernism period and is represented by dynamic decomposition, dissolved forms and technological advance. Next to futurism, photorealism is another successor of modernism aesthetics in contemporary art 
games that embodies realistic impressions designed as close to the physical space as possible to erase the gap between the virtual and natural worlds.

\section{Conclusions}

The author of this article has previously analyzed the trends in digital art games, namely, glitch, pixel art, hacking, vaporwave, generative art, kitsch/camp, naïve art, and noise music. In the framework of her postdoctoral research project, the author presents a comprehensive stylistic analysis of art games related to modernism heritage. Her intention is to fill the gap of aesthetical analysis in the game discourse where only a few examples contain references to the historical styles and aesthetical theory of the games. As a proper analysis of the art game trends demands a detailed outline which cannot be placed in a single article, this paper is focused on photorealism and futurism. Therefore, the study of other trends lies outside the scope of this paper.

This study discusses the most prominent art games in the field of photorealism and futurism and describes the new game, Art Space, which will incorporate the historical antecedents of art games and other art media such as paintings, costumes, and music. The game will keep the structure of the art games classification model envisaged in this article in order to show the most visible aesthetic trends in art games to the player.

Mission of the project is to encourage the manifestation of knowledge in the future art games. The project aims to promote the discussion of art research in the art game discourse. It intends to explain the specific means of expression governing the contemporary game language and to show the new trends in the context of their cultural backgrounds.

This paper is devoted to the aesthetical heritage, but the suggested methodological approach of research and knowledge transfer is certainly not limited to the area of aesthetics: it encompasses all subjects of modern art research. The article speaks to art game designers and theorists, and suggests creating a new niche of art games that would encompass the research results into contemporary art and transfer those results to the general public of players. The new game Art Space is presented as an example of this approach. It illustrates the principle of how research results could be manifested in the game. Art Space belongs to the large number of games which have the goal of supporting knowledge of culture yet it hopes to open a new page in edugames devoted to research into contemporary art. 


\section{Acknowledgements}

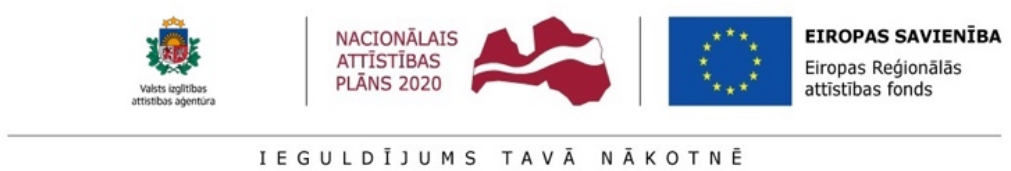

This research has been supported by a grant from the European Regional Development Fund project "Leveraging ICT product innovations by enhancing codes of modern art"

No. 1.1.1.2/VIAA/1/16/106 within the Activity 1.1.1.2 "Post-doctoral Research Aid”. Many thanks to Wayne Chislett for his very kind support and proofreading.

\section{References}

Almeida, M.S.O., \& da Silva, F.C.S. (2013). A Systematic Review of Game Design Methods and Tools. $12^{\text {th }}$ International Conference on Entertainment Computing, 17-29. DOI:10.1007/978-3-642-41106-9_3.

Becker, K., \& Parker, J. (2014). Methods of Design: An Overview of Game Design Techniques. In J. Schrier (Ed.), Learning, Education and Games (pp.179-198). Pittsburgh: ETC Press.

Clark, J. (2016). Bound, Review. Retrieved from https://www.gamespot.com/images/13003112048

Diver, M. (2017). Dear Esther Live, Interview. Retrieved from https://www.warwickartscentre. co.uk/news/2017-2/11/dear-esther-live-interview-/

Djaouti, D., Alvarez, J., \& Jessel, J.-P. (2011). Classifying Serious Games: The G/P/S Model. In P. Felicia (Ed.), Handbook of Research on Improving Learning and Motivation through Educational Games: Multidisciplinary Approaches (pp. 118-136). Hershey, Derry Township.

Djaouti, D., Alvarez, J., Jessel, J.-P., \& Methel, G. (2008). Towards a Classification of Video Games. International Journal of Computer Games Technology. Retrieved from http://www.ludoscience.com/files/ressources/aisb07_towards_a_classificatio.pdf

Drucker, J. (2014). Graphesis: Visual Forms of Knowledge. Harvard University Press.

Elverdam, C., \& Aarseth, E. (2007). Construction Through Critical Analysis. Games and Culture, 2(1). Sage Publications. Retrieved from http://nideffer.net/classes/27008/week_05_design/classification_and_design_aarseth_elverdam.pdf

Flanagan, M. (2009). Critical Play: Radical Game Design. Cambridge etc.: The MIT Press.

Gee, L.L.S., \& Dolah, J. (2018). Influence of Form, Texture and Shading on 'Abstract' and 'Realistic' Style Preferences: An Overview of Design Characteristics through Incidental Thematic Results. Advances in Social Science, Education and Humanities Research, 207 ( $3^{\text {rd }}$ International Conference on Creative Media, Design and Technology), 38-43.

Gintere, I., Zagorskis, V., \& Kapenieks, A. (2018). Concepts of E-learning Accessibility Improvement - Codes of New Media Art and User Behaviour Study. 10th CSEDU International Conference on Computer Supported Education, 1, 426-431. DOI: 10.5220/0006787304260431.

Gintere, I. (2019a). A New Digital Art Game: The Art of the Future. Society. Integration. Education”, 4, 346-360. DOI: http://dx.doi.org/10.17770/sie2019vol4.3674

Gintere, I. (2019b). Towards a New Digital Game of Contemporary Aesthetics: Research and Knowledge Transfer. Society. Technology. Solutions. Valmiera: Vidzeme University of Applied Sciences. April 25th-26th, 2019 [accepted to be published]. 
Gintere, I. (2020). The Inclusion of Research and Knowledge Transfer in Art Games. Proceedings of the International Scientific Conference "New Challenges in Economic and Business Development”, May $14^{\text {th }}-16^{\text {th }}$. Riga: University of Latvia [accepted to be published].

Grant, J., \& Vysniauskas, A. (2004). Digital Art for the 21st Century: Renderosity. London: AAPPL Artists' and Photographers' Press Ltd.

Grau, O. (2003). Virtual Art: from Illusion to Immersion. The MIT Press.

Haines, D., \& Hinterding, J. (2011). The Outlands. Retrieved from http://www.haineshinterding.net/2011/06/29/the-outlands/

Homolka, S., Price, B.A., \& Sutherland, K. (2007). The Remaking of a Modernist Icon: Marcel Duchamp's Nude Descending a Staircase (No. 3). The Book \& Paper Group/ICOM-CC Graphic Documents Joint Session, AIC 35th Annual Meeting, 45-52. Retrieved from https://cool.conservation-us.org/coolaic/sg/bpg/annual/v26/bp26-07.pdf

Jakdonlan. (2019). Visual Style and Graphics in Games. Retrieved from https://jakdonlan. wordpress.com/about/visual-style-and-graphics-in-games/

Jansson, M. (2010). Game Art: John Paul Bichard, a Pioneer of In-Game Photography. GameScenes: Art in the Age of Videogames, Retrieved from https://www.gamescenes. org/2010/11/interview-with-john-paul-bichard-pioneer-of-in-game-photography.html

Järvinen, A. (2002). Gran Stylissimo: The Audiovisual Elements and Styles in Computer and Videogames. Proceedings of Computer Games and Digital Cultures Conference, 113-128.

Kane, C.L. (2014). Chromatic Algorithms: Synthetic Color, Computer Art, and Aesthetics after Code. Chicago, London: University of Chicago Press.

Kleckner, S. (2014). Digital Futurism: A Discussion about a Popular Video Game Art Style (part 1). Retrieved from https://venturebeat.com/2014/08/02/digital-futurism-part-1-adiscussion-about-a-popular-video-game-art-style/

Koc, A. (2017). Do You Want Vaporwave, or Do You Want the Truth? Cognitive Mapping of Late Capitalist Affect in the Virtual Lifeworld of Vaporwave. Capacious: Journal of Emerging Affect Inquiry, 1(1), 57-76.

Kūlis, M. (2015). Saskaņu māksla. Datori. Grafika. Dizains. Rīga: Jāņa Rozes apgāds.

Lieser, W. (2010). The World of Digital Art. Potsdam: Tandem Verlag GmbH.

Lovejoy, M. (2004). Digital Currents: Art in the Electronic Age. London: Routledge.

Mayer, I., Bekebrede, G., Harteveld, C., Warmelink, H., et al. (2014). The research and Evaluation of Serious Games: Toward a Comprehensive Methodology. British Journal of Educational Technology, 45(3), 502-527. DOI: 10.1111/bjet.12067.

Paul, C. (2003). Digital Art. London: Thames \& Hudson.

Pearce, C. (2006). The Aesthetics of Play. Visible Language, 40(1). California: Rhode Island School of Design, 66-89.

Plastic Studios. (2016). Bound. Retrieved from https://www.youtube.com/ watch?v=aE37l6RvF-c\&frags $=$ pl\%2Cwn

Pring, R. (2003). Www.colour: Effective Use of Colour for Web Page Design. London: Cassel Illustrated.

Quaranta, D. (2006). Game Aesthetics: How Videogames are Transforming Contemporary Art. In D. Quaranta \& M. Bittanti (Eds.), GameScenes: Art in the Age of Videogames (pp. 297308). Milan: Johan and Levi.

The Chinese Room. (2012). Dear Esther. Retrieved from https://www.youtube.com/watch?v= hlGdbziSwEY\&frags=pl\%2Cwn 
Gintere, 2020. Art Space: an Experimental Digital Art Gam

Waern, A., \& Back, J. (2015). Experimental Game Design. In P. Lankoski \& S. Björk (Eds.), Game Research Methods: An Overview (pp. 341-354). [Pittsburgh:] ETC Press.

Wiedermann, J. (Ed.) (2002). Taschen's 1000 Favourite Websites. Köln, London, etc.: Taschen. Wolf, M.J.P. (2003). Abstraction in the Video Game. In M. J. P. Wolf \& B. Perron (Eds.), The Video Game Theory Reader (pp. 47-57). New York, London: Routledge. 